International Journal of Biology, Pharmacy and Allied Sciences (IJBPAS) 'A Bridge Betuen caboratory and QReado'

Www.ibpas.com

\title{
ROOT MORPHOLOGY, SHOOT GROWTH, ANTIOXIDATIVE RESPONSE AND GAS EXCHANGE OF STEM CUTTINGS OF Jatropha Curcas $L$. ACCESSIONS AT DIFFERENT NACL SALINITY LEVELS
}

\section{SUJATHA EDUPUGANTI ${ }^{* 1}$, SUDHIR EJNAVARZALA ${ }^{2}$, NIRMALA BABU RAO ${ }^{3}$ AND P. KAMALAKAR ${ }^{4}$}

1: Associate Professor, Dept of Botany, Osmania University, Hyderabad, India

2: Research Scholar, Dept of Botany, Osmania University, Hyderabad, India

3: Professor, Dept of Botany, Osmania University, Hyderabad, India

4: Professor, Dept of Botany, Osmania University, Hyderabad, India

*Corresponding Author: Sujatha Edupuganti: E Mail: $\underline{\text { sujatha@osmania.ac.in }}$

Received 25 ${ }^{\text {th }}$ June 2021; Revised $28^{\text {th }}$ July 2021; Accepted 29 ${ }^{\text {th }}$ Aug. 2021; Available online $25^{\text {th }}$ Sept. 2021

$$
\text { https://doi.org/10.31032/IJBPAS/2021/10.9.1033 }
$$

\begin{abstract}
With the growing need for biofuels, Jatropha, a rugged plant with a lot of energy potential, is being evaluated as one of the biofuel crops that can thrive in harsh conditions such as dryness and salinity are common in arid and semi-arid environments. Salt stress is one of the environmental factors that greatly limit crop development and production worldwide. The objective of this study was to examine the effects of $3 \mathrm{NaCl}$ salinity levels $(0,100$, and $120 \mathrm{mM})$ on the root morphology, shoot growth, antioxidative defense response, and gas exchange parameters of stem cuttings of six Jatropha accessions (viz., A6002, A6004, A6008, A6007 A6011 and A6014) at 180 days after treatment (DAT) and 360 DAT. Jatropha accessions were subjected to $100 \mathrm{mM}$ and $15 \mathrm{mM} \mathrm{NaCl}$ treatment for 360 days. There was considerable variation in the root system, shoot growth, and antioxidative defense response and gas exchange among
\end{abstract}


these accessions. The root morphology parameters such as length, diameter, volume, and dry weight were significantly affected in A6002, A6004, A6007, and A6008 accessions.

Moreover, the above accessions are sensitive to salinity as leaf area, shoot growth (plant height, stem diameter and shoot dry weight), gas exchange measurements, and SPAD chlorophyll was significantly decreased at $150 \mathrm{mM} \mathrm{NaCl}$ at 360 DAT. However, the accessions A6011 and A6014 maintaining carboxylation efficiency incorporated no significant decline in the root system, shoot growth at $150 \mathrm{mM} \mathrm{NaCl}$ at 360 DAT. Antioxidative defense enzyme activities such as SOD, CAT, APX, GR, and proline levels were up at both salinity treatments. Still, MDA levels were down in A6011, and A6014 accessions, indicating that oxidative damage was minimized, and membrane integrity was preserved. A6002, A6004, A6007, and A6008 accessions experienced substantial oxidative stress at the end of the trial. Thus, we can conclude that $\mathrm{A} 6011$ and $\mathrm{A} 6014$ accessions were more resistant to $\mathrm{NaCl}$ stress, whereas A6002, A6004, A6007, and A6008 accessions were more sensitive.

\section{Keywords: Jatropha, Stress, Salinity, Gas exchange, Antioxidative response}

\section{INTRODUCTION}

Salinity is one of the major abiotic stress factors, and approximately $23 \%$ of cultivated land was affected. The impact of environmental stress around the world caused by salinity is constantly expanding in many parts of the world, particularly in arid and semi-arid areas, because agriculture expanding to these regions with modern irrigation practices will exacerbate secondary salinization [1, 2]. Globally, about $1128 \mathrm{~m}$ ha area is affected by salinity and sodicity stresses. About 6.73 million ha soil is affected by salinity in Indian states such as Gujarat (2.23 m ha), Uttar Pradesh (1.37 m ha), Maharashtra (0.61 m ha), West Bengal (0.44 m ha), and Rajasthan (0.38 m ha), accounting for almost $75 \%$ of saline and sodic soils [3, 4]. Salinity has negative impacts on plant growth, and agricultural yield in saline soils is low. At the moment, $\mathrm{NaCl}$ is the most widely used type of salt, and it causes significant damage. Beyond the threshold levels, sodium chloride $(\mathrm{NaCl})$ in the soil generates ionic imbalance. It disrupts ion homeostasis in plant cells, causing selective ionic toxicity and lowering root osmotic potential, all of which damage plant cell physiology and hinder plant growth [5, 6].

Furthermore, salinity stress reduces $\mathrm{K}+$, $\mathrm{Ca} 2+, \mathrm{Zn} 2+$, and $\mathrm{Mn} 2+$ uptake by plant roots due to $\mathrm{Na}+$ competition at the root surface, 
altering the distribution and supply of these minerals in plants $[7,8]$. On the saline ground, waterlogging and soil compaction are regular occurrences, resulting in low $\mathrm{O}_{2}$ levels and hypoxic stress. Plant roots require enough oxygen to generate ATP from carbohydrates. Plant roots cannot obtain enough energy to maintain health and regular physiological activity under hypoxic environments. Root absorption of $\mathrm{Na}+$ and $\mathrm{Cl}$ increases when the rhizosphere's $\mathrm{O}_{2}$ level decreases [9]. High concentrations of $\mathrm{Na}^{+}$ and $\mathrm{Cl}^{-}$ions in leaves decrease the assimilation of photosynthetic $\mathrm{CO}_{2}$ by affecting the stomatal and non-stomatal components $[\mathbf{1 0}, \mathbf{1 1}]$.

The Euphorbiaceous family includes Jatropha curcas L. (Barbados nut, physic nut), a tropical and subtropical perennial shrub endemic to tropical America. J. curcas has attracted a lot of interest as a renewable energy source because its seeds contain between 28 and 38 percent oil [12], which may be esterified with methanol to produce high-quality biodiesel that fulfills American and European requirements [13]. Jatropha genus has a remarkable combination of valuable traits with high adaptability to various environmental conditions (semi-arid climates) and soils (marginal soils). The capacity for heavy metal bioremediation, ease of propagation by grafting or seed, widespread natural ranges, and expansive growth make it a unique plant $[\mathbf{1 4}, \mathbf{1 5}]$. It is now being adopted in various tropical and subtropical areas of Africa and Asia with considerable success [16]. In recent years, Jatropha has been widely introduced in several Indian states to promote the country's biodiesel program. The government of India set a goal of developing 4 lakh hectares (ha) of land for the Jatropha plantation over five years as part of a national biodiesel mission [17]. Plant growth and yield must be regulated to successfully apply the Jatropha plantation in semi-arid and arid regions where salinity is a frequent occurrence. As a result, it is critical to understand the Jatropha root system, growth, and physiological responses to salt in semi-arid and arid environments. In this study, root system, growth, antioxidative defense response and gas exchange responses (photosynthesis, transpiration, and leaf conductance) of Jatropha under different concentrations of $\mathrm{NaCl}$ were investigated.

\section{MATERIAL AND METHODS}

\section{Plant material}

The six J. curcas accessions viz., A6002, A6004, A6008, A6007 A6011, and A6014 were selected randomly from ICRISAT Jatropha collections (ICJC) and National 
Bureau of Plant Genetic Resources (NBPGR) germ-plasm collections. Three months before the start of the experiment, healthy and uniform stem-cuttings were collected from the basal portion of 3-year-old J. curcas mother plants accessions early in the morning. The cuttings were $12-15 \mathrm{~cm}$ in length and 3 to $4 \mathrm{~cm}$ thick with 4 to 5 nodes short internodes.

Growth, experimental design and salt treatments

On the same day, stem cuttings were inserted at10-15 cm depth into pots $(18 \mathrm{~cm}$ height $\times 16 \mathrm{~cm}$ diameter) filled with $15 \mathrm{~kg}$ of soil mixture consisting of sand and red soil in the ratio of 1:2. After inserting the cuttings, all polybags were watered at two-day intervals throughout the experimental period. These pots were then placed in a shaded net for initial management and were watered as needed. Thinning was done during the third month after sowing, and only one healthy plant was kept. Plants were subjected to three different salt treatments of $0,100 \mathrm{mM}$, and $150 \mathrm{mM} \mathrm{NaCl}$ after three months of acclimation. Salt concentrations were stepped up in $25 \mathrm{mM}$ per day increments until final concentrations $(100 \mathrm{mM}$ and $150 \mathrm{mM} \mathrm{NaCl})$ were achieved to avoid sudden osmatic shock. All plant was irrigated daily, according to the treatment, with $800 \mathrm{~mL}$ of saline solution (enough volume to occur leaching), in the early hours of the morning (06:00-07:00 h). The pots were sealed at the bottom to prevent leaching and to minimize soil evaporation covered with cartons wrapped with aluminum folio. A few pots were weighed periodically to note the loss of moisture, and soft water was added to make up for the deficiency. During the experiment, daily water loss was measured at 9:00 a.m. by recording the weight of pots and tap water was supplied to $90 \%$ of water holding capacity. Care was taken not to water excessively to prevent waterlogging. Weeds were periodically hand removed, and occasionally $2 \mathrm{gm} \mathrm{L}^{-1}$ Bordeaux mixture was sprayed after spotting powdery mildew on leaves and stems. This study was carried out in the glasshouse of the Botany Department, Osmania University, Hyderabad, with a day/night temperature of $28 / 24{ }^{\circ} \mathrm{C}$ and relative humidity between $70 \%-80 \%$ and 800 to $1000 \mu \mathrm{mol} \mathrm{m}^{-2} \mathrm{~s}^{-1}$ maximum photosynthetic photon flux. The experimental design was a randomized complete block in a split-plot layout with three replications. The experiments were repeated three times with similar results each time.

\section{Data collection}

Nondestructive measurements of growth were taken 180 days after treatment (DAT) 
and 360 DAT. For each pot, plant height, stem diameter, shoot dry weight leaf area and SPAD chlorophyll measurements were taken. At the end of the experiment, plants were harvested and separated into shoots and roots, and root morphology parameters were measured.

\section{Growth attributes}

Stem girth: Vernier calipers were used to measure the stem diameter of each plant ( 5 $\mathrm{cm})$ above the soil surface.

Plant height: Observations were recorded using a ruler; if the plant was more than 30 $\mathrm{cm}$, it was measured by marking the plant at the end of $30 \mathrm{~cm}$.

Leaf area: Leaf area was recorded with an LI-3100 leaf area meter (LI-COR. Inc., Lincoln, NE, USA).

Shoot and root dry weight: After harvesting, shoots and roots were covered with paper bags and placed in an oven at $60{ }^{\circ} \mathrm{C}$ for three days to a constant weight, and weights were recorded.

Root parameters: The aboveground sections of the Jatropha plants were removed after 360 days of maturation, and the soil in the pot was placed on a 100-mesh steel sieve, moistened, and gently rinsed to separate the roots from the soil. After that, the absorbent paper was used to dry the roots. The roots were placed in a clear dish with $10 \mathrm{~mm}$ of water in it. An Epson Perfection V700 scanner was used to scan the trays and create a grayscale image. The total root length, surface area, volume, and diameter were calculated using the WinRHIZO Pro image processing system (Regent Instruments Inc., 2672, Canada).

Gas exchange measurements: Leaf gas exchange parameters were measured on young, fully expanded leaves from the upper crown of plants. Net photosynthetic rate (Pn), transpiration rate (E), and stomatal conductance (Gs) were measured using an LI-COR, 6400 portable photosynthetic system (LI-COR, Lincoln, NE, USA) under controlled conditions of photosynthetic photon flux density (PPFD) (1000-1500 $\mu \mathrm{mol}$ $\mathrm{m}^{-2} \mathrm{~s}^{-1}$ ) and, to air-vapor pressure deficit $(15-20 \mathrm{kPa})$ and, the temperature, $\mathrm{CO}_{2}$ concentration and relative humidity inside the leaf cuvette were always close to ambient air values. These measurements were carried out on the middle part of the youngest (fully opened second leaf), which avoided the leaf vein from 8:30 to 10:00 a.m.

Chlorophyll content: SPAD (Soil Plant Analysis Development) was used to calculate the chlorophyll content. The reading of a chlorophyll meter (SPAD-502, Minolta) is a unitless value that gives an estimate of the amount of chlorophyll in the leaves by 
measuring the intensity of green color variation between light disintegration at 430 $\mathrm{nm}$ and $750 \mathrm{~nm}$. The SPAD chlorophyll reading was taken from the intermodal position on the main stem on the fully expanded secondary leaf.

Lipid peroxidation: The malondialdehyde (MDA) content was estimated to determine lipid peroxidation using Heath and Packer's method (1968). One gram of Jatropha leaf material was macerated in $5 \mathrm{ml}$ of $0.1 \%$ $(\mathrm{w} / \mathrm{v})$ TCA. The homogenate was centrifuged at $10,0009 \times \mathrm{g}$ for $5 \mathrm{~min}$. For $1 \mathrm{ml}$ of the aliquot of the supernatant, $4 \mathrm{ml}$ of $20 \%$ TCA containing $0.5 \%$ TBA was added. The mixture was heated at $95 \mathrm{C}$ for $30 \mathrm{~min}$ and cooled quickly in an ice bath. The absorbance was measured at 532 and 600 $\mathrm{nm}$ - the extinction coefficient of $155 \mathrm{mM}^{-1}$ $\mathrm{cm}^{-}$was used to calculate the concentration of MDA.

\section{Antioxidant enzyme activities}

Fresh Jatropha leaf material (1.0 g, without petiole) was crushed with liquid nitrogen and suspended in a potassium phosphate $(50 \mathrm{mM}$, $\mathrm{pH}$ 7.5) buffer containing $1.0 \quad \mathrm{mM}$ phenylmethylsulphonyl fluoride (PMSF), 0.2 $\mathrm{mM}$ EDTA, $2 \% \mathrm{w} / \mathrm{v}$ polyvinyl pyro pyrrolidone, and $2 \% \mathrm{w} / \mathrm{v}$ polyvinyl pyro (PVPP). The homogenate was centrifuged at $15,000 \mathrm{~g}$ for 20 minutes after being squeezed through two layers of muslin fabric. The resulting supernatant was used to measure the enzyme tests $(4 \mathrm{mM}$ sodium ascorbate was for ascorbate peroxide). The amount of protein in the enzyme extract was calculated using bovine serum albumin as standard [18].

Superoxide dismutase (SOD, E.C 1.15.1.1) activity was measured to prevent the photochemical reduction of nitro blue tetrazolium (NBT) [19]. A $3 \mathrm{ml}$ of reaction mixture contained $40 \mathrm{mM}$ phosphate buffer (pH 7.8), $13 \mathrm{mM}$ methionine, 75 1M NBT, $0.1 \mathrm{mM}$ EDTA, $0.1 \mathrm{ml}$ of enzyme extract and $2 \mathrm{lM}$ riboflavin. Riboflavin was added at the end. The reaction mixture was exposed to $15-$ watt fluorescent tubes, and the decrease in the absorbance of the reaction mixture was read at $560 \mathrm{~nm}$. Fifty percent inhibition was considered as one enzyme unit.

\section{Ascorbate peroxidase (APX; E.C 1.11.1.11)} In this assay the reaction mixture contained $1.5 \mathrm{ml}$ of $50 \mathrm{mM}$ sodium phosphate buffer (pH 7), $0.2 \mathrm{mM}$ EDTA, $0.5 \mathrm{ml}$ of $0.5 \mathrm{mM}$ ascorbic acid, $0.5 \mathrm{ml} 0.5 \mathrm{mM} \mathrm{H}_{2} \mathrm{O}_{2}$ and 0.5 $\mathrm{ml}$ of enzyme sample. The activity was recorded as the decrease in absorbance at 290 $\mathrm{nm}$ for 1 minute. The amount of ascorbate oxidized was calculated from the extinction coefficient of $2.6 \mathrm{mM}^{-1} \mathrm{~cm}^{-1}$ [20].

Catalase (CAT, E.C.1.11.1.6.) The rate of $\mathrm{H}_{2} \mathrm{O}_{2}$ decomposition at $240 \mathrm{~nm}$ was measured 
spectrophotometrically and calculated using a molar extinction coefficient of $45.2 \mathrm{mM}^{-1}$ $\mathrm{cm}^{-1}$. The reaction mixture consisted of 50 $\mathrm{mM}$ phosphate buffer, $0.1 \mathrm{mM} \mathrm{H}_{2} \mathrm{O}_{2}$, and enzyme extract. One unit of catalase activity was assumed as the amount of enzyme that decomposed $1.0 \mu$ mol of $\mathrm{H}_{2} \mathrm{O}_{2}$ per $\mathrm{mg}$ of soluble protein per minute at $30{ }^{\circ} \mathrm{C}$ [21].

Free proline: Fresh leaf (0.5 g) was homogenized in $10 \mathrm{ml}$ of sulfosalicylic acid $(3 \% \mathrm{w} / \mathrm{v})$ and filtered through Whatman No.

2 filter paper. The reaction mixture was composed of $2 \mathrm{ml}$ of plant extract, $2 \mathrm{ml}$ of acid ninhydrin reagent, and $2 \mathrm{ml}$ of glacial acetic acid. The combination, as mentioned earlier, was cooked for 1 hour in test tubes in a boiling water bath. The reaction was stopped with a cold bath, then $4 \mathrm{~mL}$ of toluene was added. The ingredients were violently agitated before being separated into phases. At $520 \mathrm{~nm}$, the upper toluene phase of chromophase was read. The amount of proline present was quantified with the help of a proline standard graph [22].

\section{Statistical analysis.}

The results presented are the mean values of 5 replicates. Pots were arranged in a completely randomized block design with five replicates (pot) for each treatment. The data analyses were carried out using one-way analysis of variance (ANOVA) followed by
Post Hoc Test (Multiple Comparisons) using SPSS (SPSS Inc., Chicago, IL, USA). The differences were considered significant if $p$ was $\leq 0.05$. The mean values were compared, and lower case letters were used in figures/tables to highlight the significant differences between the treatments.

\section{RESULTS}

\section{$\mathrm{NaCl}$ salinity on root morphology}

Root length: Remarkable root length arrest was noticed in A2 and A7 accessions of stem cuttings by $21 \% \quad(\mathrm{p}=0.045)$ and $25 \%$ $(p=0.017)$ respectively at $100 \mathrm{mM} \mathrm{NaCl}$ treatment compared to the control. At 150 $\mathrm{mM} \mathrm{NaCl}$ treatment further significantly reduced the root length in $\mathrm{A} 2$ and $\mathrm{A} 7$ accessions. When compared to the comparable controls, salt stress at $100 \mathrm{mM}$ $\mathrm{NaCl}$ had a negligible influence on root length growth in the A4, A8, A11, and A14 accessions. The $150 \mathrm{mM}$ salinity treatment, on the other hand, reduced the root length in the above accessions propagated by stem cuttings (by $7-15 \%$ ). This data suggests that A4, A8, A11, and A14 accessions stem cuttings resulted in greater root length than A2 and A7 accessions. Considerable variations were observed among the accessions for root length under salt stress (Fig. 1A). 
Root volume and root diameter: In comparison to control, root volume in Jatropha plants established from stem cuttings was reduced by $23-27 \% \quad(p<0.05)$ and $31-34 \%(\mathrm{p}<0.05)$ at $100 \mathrm{mM}$ and 150 $\mathrm{mM} \mathrm{NaCl}$ treatments, respectively, in the $\mathrm{A} 2$, A7, and A8 accessions. Root volume was not considerably reduced in A4, A11, and A14 accessions at tested salinity regimes compared to the control (Fig. 1B). Root diameter enlargement was marginally arrested in all tested accessions at $100 \mathrm{mM}$ $\mathrm{NaCl}$ treatment cover their respective controls. At highest salinity treatment, root diameter enlargement was significantly $(p<0.05)$ reduced in $A 2, A 7$ and A8 accessions by 28,21 , and $22 \%$, respectively, compared to the control. Whereas, in A4, A11, and A14 accessions root diameter enlargement was marginally affected. Among the accessions root diameter was not significantly varied under control and stress conditions. Root volume was considerably higher in A2 and A8 accessions under control treatments among the accessions (Fig. 1B \& C).

Root dry weight: Root dry weight showed a significant reduction in $\mathrm{A} 2, \mathrm{~A} 4, \mathrm{~A} 7$, and $\mathrm{A} 8$ accessions by $27,19,18$, and $33 \%$, respectively, at $100 \mathrm{mM} \mathrm{NaCl}$ treatment. The decline was more pronounced $(\mathrm{p}<0.05)$ at
$150 \mathrm{mM} \mathrm{NaCl}$ treatment by $71,38,49$, and $36 \%$ in $\mathrm{A} 2, \mathrm{~A} 4, \mathrm{~A} 7$, and $\mathrm{A} 8$ accessions, respectively. Compared to the control, the accessions A11 and A14 did not significantly reduce root dry weight at any of the salinity regimes investigated (Fig. 1D).

\section{$\mathrm{NaCl}$ salinity on shoot growth}

Plant height: In this study, a 180-day treatment with $100 \mathrm{mM} \mathrm{NaCl}$ resulted in a modest reduction in plant height in all stemcutting-raised accessions. At 180 DAT, the highest salinity treatment resulted in a significant $(\mathrm{p}<0.05)$ reduction in plant height in $\mathrm{A} 2, \mathrm{~A} 4, \mathrm{~A} 8$, and $\mathrm{A} 7$, respectively, by 21 , 23,27 , and $23 \%$ compared to the control. At 360 DAT, accessions treated with 100 and $150 \mathrm{mM} \mathrm{NaCl}$ showed a similar pattern. In A2, A4, A7, and A8 accessions, plant height was low, indicating a lack of tolerance to salt stress. Under salinity conditions, the A11 and A14 accessions did not suffer from low plant height. Under control conditions, the magnitude of variation in plant height among the accessions was minor (Fig. 2A\&B).

Stem girth: Under salt stress, stem girth enlargement was inhibited in Jatropha accessions propagated by stem cuttings. In comparison to the control, $150 \mathrm{mM} \mathrm{NaCl}$ treatment for 180 days reduced stem girth enlargement by $22 \%(p=0.025)$ and $29 \%$ $(\mathrm{p}=0.009)$ in A2 and A7 accessions, 
respectively. At 180 DAT, salinity had a minor effect on stem girth enlargement in the A8, A4, A11, and A14 accessions. At 360 DAT, both $100 \mathrm{mM}$ and $150 \mathrm{mM} \mathrm{NaCl}$ treatments resulted in a significant $(p<0.05)$ reduction of stem girth in A2 and A7 accessions compared to their control. Both $100 \mathrm{mM}$ and $150 \mathrm{mM} \mathrm{NaCl}$ treatments resulted in a marginal reduction in stem girth of A8, A4, A11, and A14 accessions at 360 DAT, respectively. Stem girth response varied among accessions considerably (Fig. 2C\&D).

Leaf area: At 180DAT, the leaf area of the A2, A7, and A8 accessions was reduced significantly $(p<0.05)$ by $20-40 \%$ and 38 $49 \%$ on average, respectively, at $100 \mathrm{mM}$ and $150 \mathrm{mM}$ salinity treatments. At 360 DAT, the above accessions had an average reduction in leaf area of $13-28 \%$ and $22-33 \%$ at $100 \mathrm{mM}$ and $150 \mathrm{mM}$ salinity treatments, respectively. At 360 days after treatment, there was no significant reduction in leaf area in A4 (15\%; p=0.061), A11 (14\%; $\mathrm{p}=0.074)$, or A14 $(12 \% ; \mathrm{p}=0.08)$. Leaf area varied significantly $(\mathrm{p}<0.05)$ among the accessions Jatropha A4, A11, and A14 accessions had greater leaf area than other accessions under the highest salinity treatment and control conditions (Fig. 2E\&F).
Shoot dry weight: Our findings demonstrated substantial $(\mathrm{p}<0.05)$ changes in dry shoot and dry root mass in $J$. curcas accessions exposed to various salt levels. At $100 \mathrm{mM}$ salinity, the average shoot dry mass was lowered by $21-50 \%(\mathrm{p}<0.05)$, and reduction was further increased to $24-69 \%$ in A2, A4, A7, and A8 accessions at $150 \mathrm{mM} \mathrm{NaCl}$ treatment at 360 DAT. There was no marked decrease in dry shoot mass of A11 and A14 accessions at $100 \mathrm{mM} \mathrm{NaCl}$ (by $16 \%$ and $7 \%$ respectively) and $150 \mathrm{Mm} \mathrm{NaCl}(18 \%$ and 16\% respectively) treatments (Fig. 1E).

\section{$\mathrm{NaCl}$ salinity on gas exchange measurements}

Net photosynthetic (Pn) response was varied among Jatropha accessions at different $\mathrm{NaCl}$ concentrations. Accessions A2, A7 and A8 exhibited the significant $(\mathrm{p}<0.05)$ reduction of Pn by 29, 21 and $26 \%$ at $100 \mathrm{mM} \mathrm{NaCl}$ treatment and by 31,24 , and $35 \%$ at 150 $\mathrm{mM} \mathrm{NaCl}$ treatment at 180 DAS, respectively in comparison with control. At 360 DAS, average Pn reduction was low but significant at $100 \mathrm{mM}$ salinity (by 19-26\%) and $150 \mathrm{mM}$ salinity (by 22- 33\%), respectively, over the control. Both at tested periods and salinity regimes A4, A11, and A14 did not experience any significant $(p>0.05)$ decrease in net photosynthesis (Fig. 3A\&B). 
The average stomatal conductance (Gs) was varied in accessions propagated by stem cutting transplants challenged with salt stress. The Gs of A2, A7, and A8 accessions displayed an average decrease of 29,24 , and $40 \%$ at $100 \mathrm{mM} \mathrm{NaCl}$ and 30, 28, and 57\% at $150 \mathrm{mM} \mathrm{NaCl}$, respectively at 180 DAS corresponding to their controls. At 360 DAS, the above accessions recorded with marked $(p<0.05)$ decrease in Gs over their respective controls, but the decline was less than that of reduction at 180 DAS at both tested salinity regimes. Whereas, there was no significant reduction of $\mathrm{Gs}$ of $\mathrm{A} 4, \mathrm{~A} 11$, and $\mathrm{A} 14$ accessions at 100 and $150 \mathrm{mM} \mathrm{NaCl}$ treatments at both tested periods compared to controls (Fig. 3C\&D).

The transpiration rate $(E)$ was reduced in all plants propagated via stem cutting propagation as the $\mathrm{NaCl}$ concentration was increased. At $180 \mathrm{DAS}$, the average $\mathrm{E}$ in $\mathrm{A} 2$, A4, A7, and A8 accessions was lowered by $22-62 \%$ at $100 \mathrm{mM}$ salinity and $23-70 \%$ at $150 \mathrm{mM} \mathrm{NaCl}$, respectively. At $150 \mathrm{mM}$ $\mathrm{NaCl}$ treatment, the $\mathrm{A} 2, \mathrm{~A} 4, \mathrm{~A} 7$, and $\mathrm{A} 8$ accessions showed an average reduction in $\mathrm{E}$ of $35-69 \%(\mathrm{p}<0.05)$ at 360 DAS. At 100 $\mathrm{mM} \mathrm{NaCl}$ treatment, the accessions $\mathrm{A} 11$ and A14 had substantial reductions in E of $27 \%$ $(\mathrm{p}=0.019)$ and $23 \%(\mathrm{p}=0.036)$, respectively, compared to the control. Under control and salinity conditions, there was a significant variance in $\mathrm{E}$ among the accessions (Fig. 3E\&F).

SPAD chlorophyll: The experimental data demonstrate a significant drop in SPAD chlorophyll value by $25-50 \%$ in A2, A7, and A8 accessions at $100 \mathrm{mM}$ salinity treatment and by $22-55 \%$ (in A2, A4, A7, A8, A11, and A14 accessions) at $150 \mathrm{mM}$ salinity treatment compared to the control at 18 DAT (Fig. 3G). At 360 DAT, $150 \mathrm{mM} \mathrm{NaCl}$ concentration also accounted for a significant $(\mathrm{p}<0.05)$ decrease in SPAD chlorophyll value, however, the degree of the decline was less than that seen at 180 DAT (Fig. 3H). There was no significant reduction in SPAD chlorophyll value with $100 \mathrm{mM} \mathrm{NaCl}$ treatment in A4, A11, and A14 accessions at both periods. There was considerable variance in chlorophyll content across the accessions under control and salinity conditions. Under salinity conditions, chlorophyll content was relatively more significant $(\mathrm{p}<0.05)$ in the $\mathrm{A} 4, \mathrm{~A} 11$, and A14 accessions (Fig. 3G\&H).

$\mathrm{NaCl}$ salinity effect on lipid peroxidation, and SOD, APX, and CAT activities and proline levels

At 180 DAT comparable to the control, MDA content was substantially $(p<0.05)$ higher in $\mathrm{A} 2$ and $\mathrm{A} 7$ accessions by $68 \%$ 
percent and $77 \%$ at $100 \mathrm{mM}$ salinity and $189 \%$ and $106 \%$ at $150 \mathrm{mM}$ salinity treatment, respectively. At 360 DAT, the accessions mentioned earlier only showed severe membrane damage at both salinity concentrations examined. At $150 \mathrm{mM} \mathrm{NaCl}$ treatment, the accessions $\mathrm{A} 8$ and $\mathrm{A} 4$ showed moderately elevated MDA levels; however, the A11 and A4 accessions did not experience significant membrane damage at both periods. This data suggest that the Jatropha accessions, A11 and A14, have comparatively low levels of membrane damage, making them highly resistant to salinity stress (Fig. 4A\&B).

Significant enhancement of SOD activity was observed in A11 and A14 accessions compared to the respective controls, periods, and investigated $\mathrm{NaCl}$ treatments. he 150 $\mathrm{mM} \mathrm{NaCl}$ treatment marginally increased the SOD activity after 180 days in accessions of A2, A7, and A8. The magnitude of SOD enhancement was lower in A2, A7, and A8 (21-25\%) accessions, whereas it was higher in $\mathrm{A} 4, \mathrm{~A} 11$, and $\mathrm{A} 14$ accessions (34-50\%) at 360 DAS, respectively (Fig. 5A\&B).

APX activity was enhanced significantly $(p<0.05)$ in all tested accessions (by an average of $28-52 \%$ ) at $100 \mathrm{mM}$ salinity treatments. APX activity was further enhanced by $34-73 \%(p<0.05)$ on average at
$150 \mathrm{mM} \mathrm{NaCl}$ at 180 DAS. At 360 DAS, the degree of increase was less in APX activity than that of 180 DAS. Jatropha accessions A11 and A14 increased their APX activity more drastically than A4 and A8 accessions, but for the accessions A2 and A7, the APX activity was lower than A4 and A8 under salinity conditions at 360 DAS (Fig. 5C\&D). When stem cutting raised accessions A2, A4, A7, and A8 were treated with $100 \mathrm{mM}$ and $150 \mathrm{mM} \mathrm{NaCl}$ for 180 days, and there was no significant difference in CAT activity. At 360 DAT, $100 \mathrm{mM}$ salinity had little effect on CAT activity, whereas $150 \mathrm{mM} \mathrm{NaCl}$ treatments increased CAT activity by 33,22 , and $36 \%$, respectively, compared to the control. At the highest salinity treatment, A11 and A14 accessions showed statistically significant increases in CAT activity of 43 and $23 \%$ at 180 DAT and 62 and $46 \%$ at 360 DAT, respectively, compared to the control (Fig. 5E\&F).

In the present study, free proline levels were significantly $(p<0.05)$ elevated by increasing the salt concentration until 180 DAT. At the highest salinity treatment, free proline levels were increased by $28-57 \%$ on an average in all screened accessions compared to their respective controls at 180 DAT. Treatments for 360 days showed no considerable improvement in proline levels in all 
accessions except A4 $(28 \% ; p=0.041)$ at

lower salinity treatment than the control. Free

proline levels of all tested accessions displayed an average increase of $19-28 \%$ at
$150 \mathrm{mM} \mathrm{NaCl}$ at $360 \mathrm{DAS}$, indicating the degree of increase declined at 360 DAS compared to 180 DAS (Fig. 6A\&B).
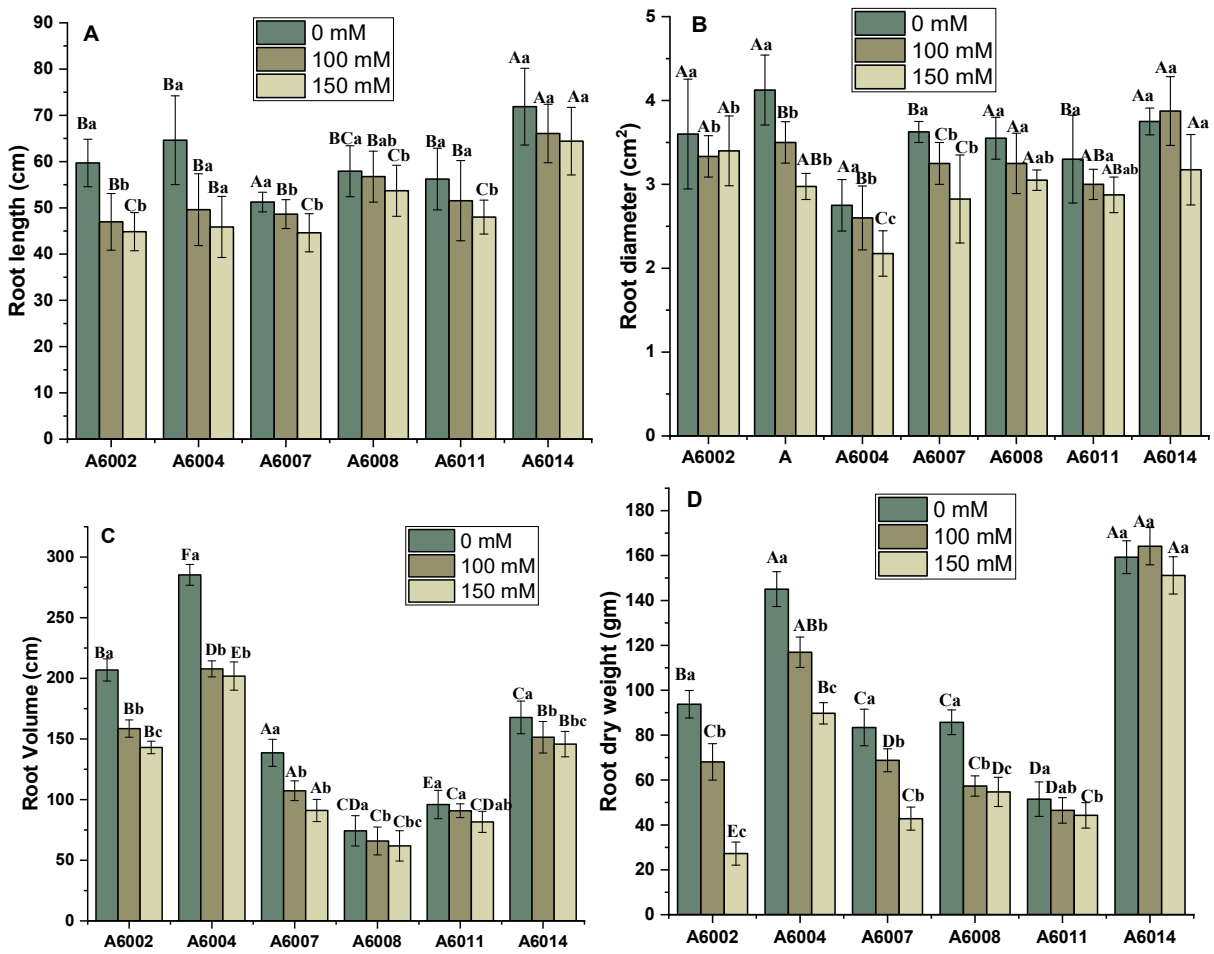

Figure 1. Root length (A), root diameter (B), root volume (C), root dry weight (E), and shoot dry weight (F) of stem cutting propagated Jatropha accessions under 0,100 , and $150 \mathrm{mM} \mathrm{NaCl}$ at the end of experiment 360 DAT. Vertical bars represent means $\pm \mathrm{SE}(n=5)$; Different letters on the top of bars denote significant differences. The small letters and capital letters indicate significant differences of salt treatments within each accession and among accessions for the same treatment, respectively at $\mathbf{p} \leq \mathbf{0 . 0 5}$ according to post hoc test 


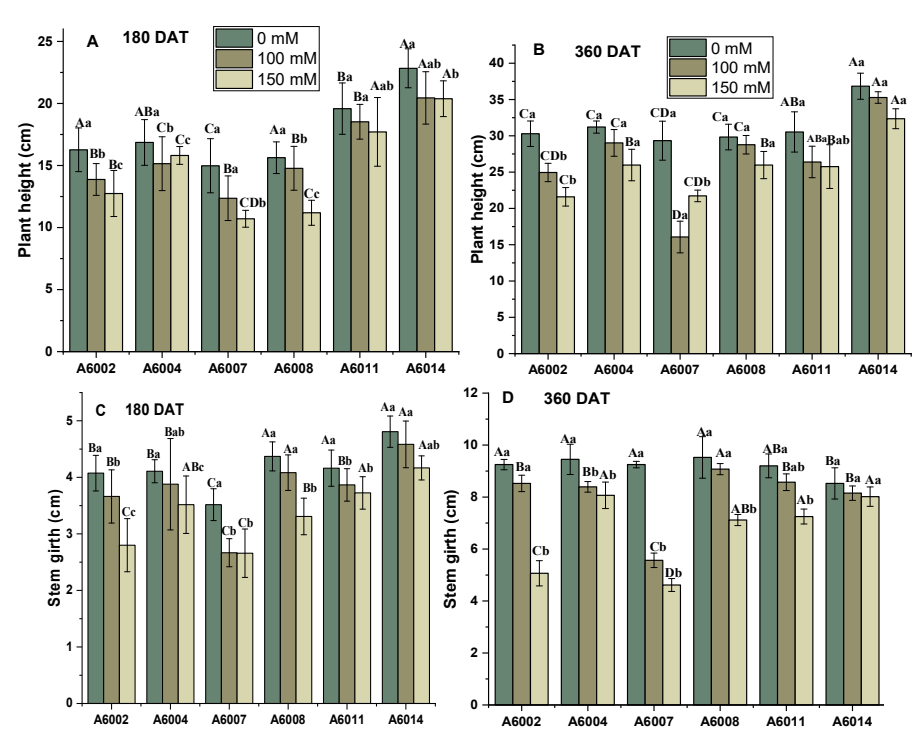

Figure 2. Plant height (A\&B), stem diameter (C\&D), and leaf area (E\&F) of stem cutting propagated Jatropha accessions under 0, 100, and $150 \mathrm{mM} \mathrm{NaCl}$ at 360 DAT. Vertical bars represent means $\pm \operatorname{SE}(n=5)$; Different letters on the top of bars denote significant differences. The small letters and capital letters indicate significant differences in salt treatments within each accession and among accessions for the same treatment, respectively at $\mathbf{p} \leq \mathbf{0 . 0 5}$ according to the post hoc test.
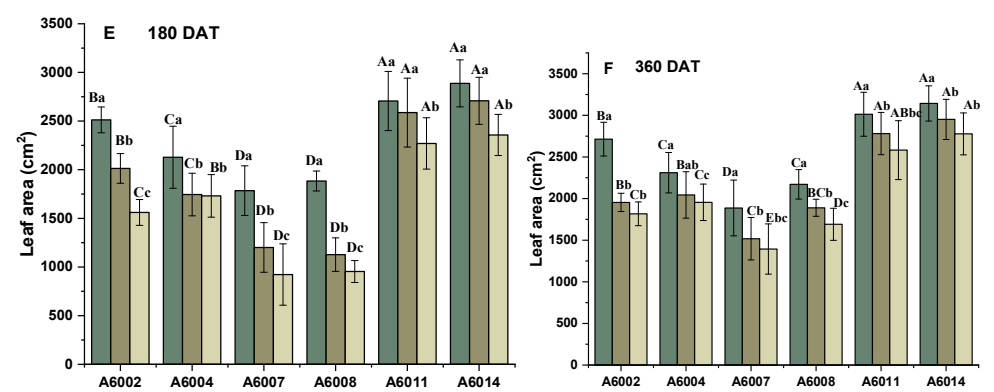

Figure 2. Leaf area (E\&F) of stem cutting propagated Jatropha accessions under 0, 100, and $150 \mathrm{mM}$ NaCl at $360 \mathrm{DAT}$. Vertical bars represent means $\pm \mathrm{SE}(n=5)$; Different letters on the top of bars denote significant differences. The small letters and capital letters indicate significant differences in salt treatments within each accession and among accessions for the same treatment, respectively at $\mathbf{p} \leq \mathbf{0 . 0 5}$ according to the post hoc test.

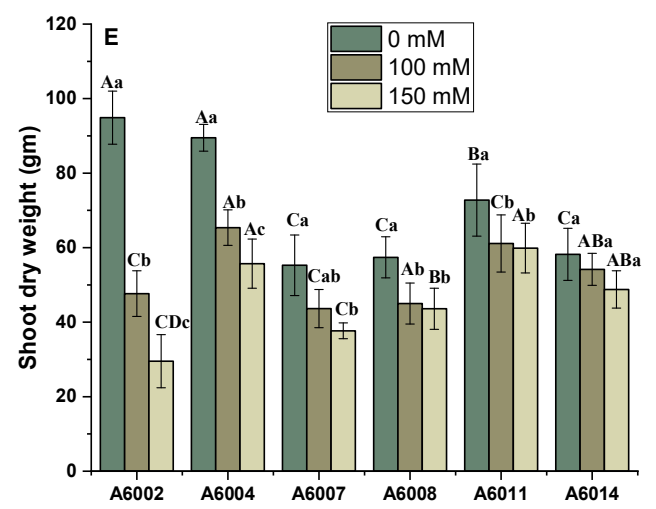

Figure 2. Root dry weight (E), of stem cutting propagated Jatropha accessions under 0 , 100, and $150 \mathrm{mM} \mathrm{NaCl}$ at the end of experiment 360 DAT. Vertical bars represent means $\pm \mathrm{SE}(n=5)$; Different letters on the top of bars denote significant differences. The small letters and capital letters indicate significant differences of salt treatments within each accession and among accessions for the same treatment, respectively at $\mathbf{p} \leq \mathbf{0 . 0 5}$ according to post hoc test 

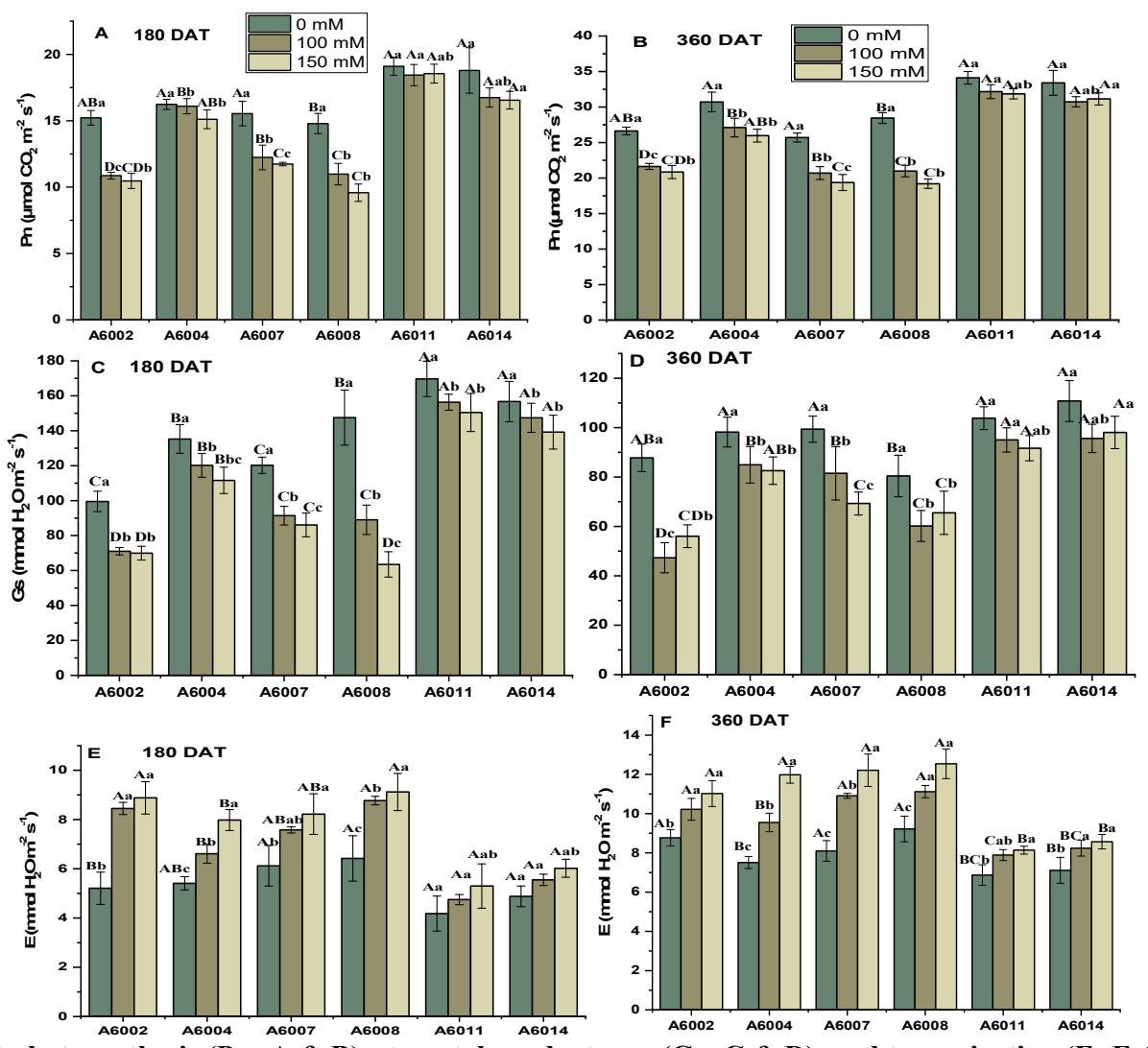

Figure 3. Net photosynthesis (Pn; A \& B), stomatal conductance (Gs; C \& D), and transpiration (E; E \& F) of stem cutting propagated Jatropha accessions under 0,100 and $150 \mathrm{mM} \mathrm{NaCl}$ at $180 \mathrm{DAT}$ and 360 DAT. Vertical bars represent means $\pm \mathrm{SE}(n=5)$; Different letters on the top of bars denote significant differences. The small letters and capital letters denote significant differences in salt treatments within each accession and among accessions for the same treatment, respectively, at $\mathbf{p} \leq \mathbf{0 . 0 5}$ according to the post hoc test.
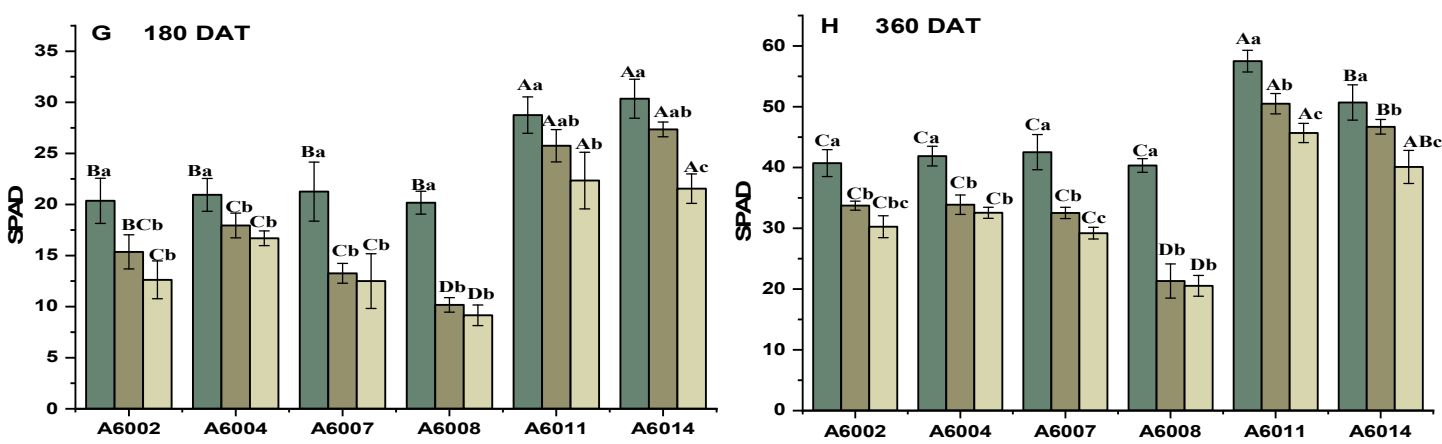

Figure 3. SPAD chlorophyll $(\mathrm{G} \& \mathrm{H})$ of stem cutting propagated Jatropha accessions under 0,100 and $150 \mathrm{mM} \mathrm{NaCl}$ at $180 \mathrm{DAT}$ and $360 \mathrm{DAT}$. Vertical bars represent means $\pm \mathrm{SE}(n=5)$; Different letters on the top of bars denote significant differences. The small letters and capital letters denote significant differences in salt treatments within each accession and among accessions for the same treatment, respectively, at $\mathbf{p} \leq \mathbf{0 . 0 5}$ according to the post hoc test. 


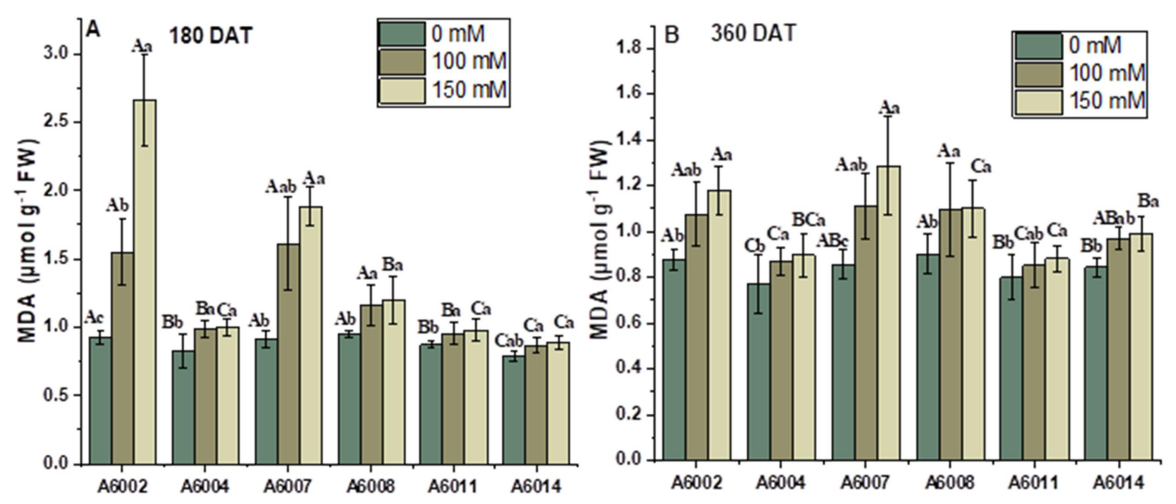

Figure 4. Effect of $\mathrm{NaCl}(0,100$, and $150 \mathrm{mM})$ treatments on lipid peroxidation in terms of malondialdehyde (MDA) content (A\&B) of stem cutting propagated Jatropha accessions at 180 DAT and 360 DAT. Vertical bars represent means $\pm \mathrm{SE}(n=5)$; Different letters on the top of bars denote significant differences. The small letters and capital letters indicate significant differences in salt treatments within each accession and among accessions for the same treatment, respectively, at $\mathbf{p} \leq \mathbf{0 . 0 5}$ according to the post hoc test.
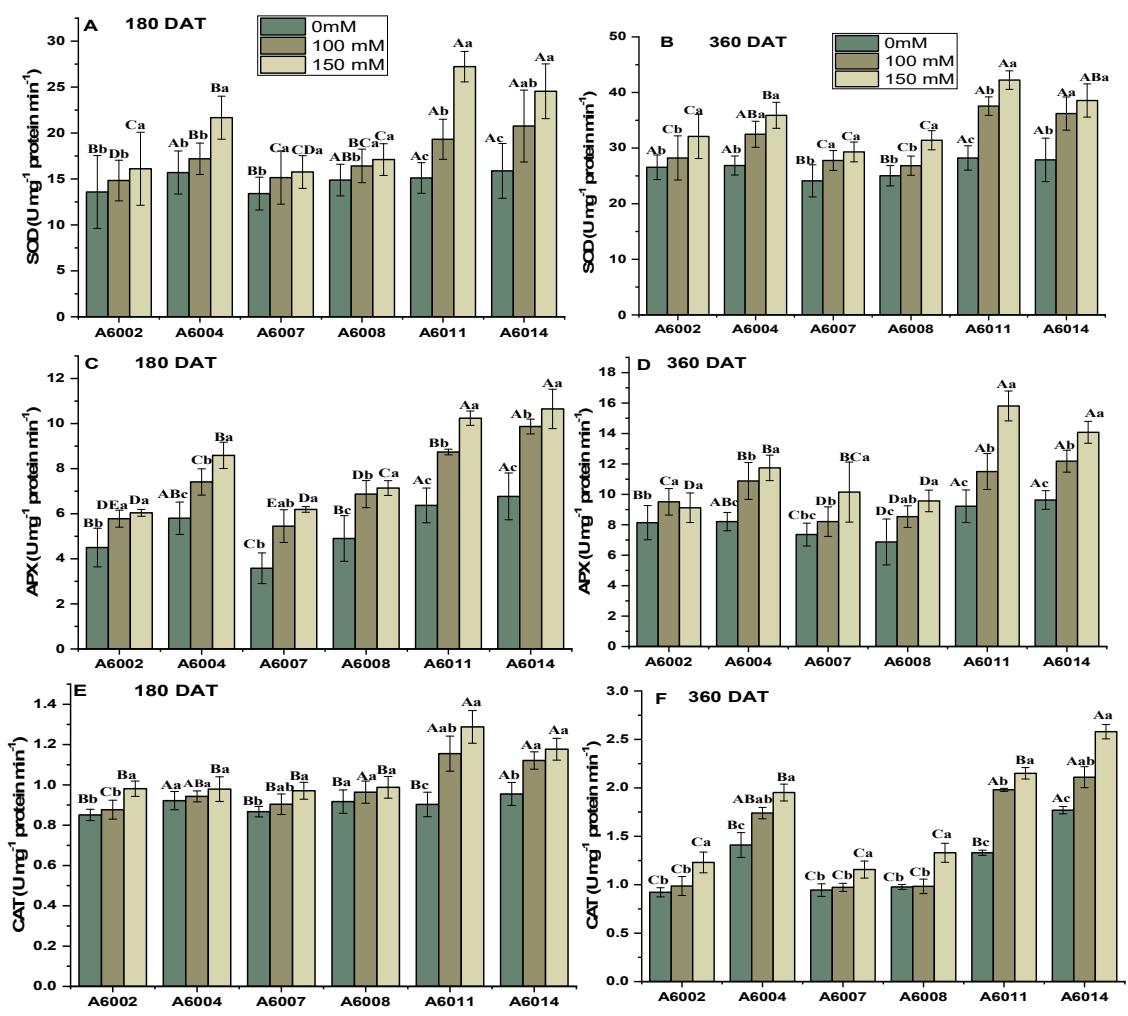

Figure 5. Effect of $\mathrm{NaCl}(0,100$ and $150 \mathrm{mM})$ treatments on superoxide dismutase (SOD; A\&B), ascorbate peroxidase

(APX; C\&D), catalase (CAT; E\&F), glutathione reductase (GR; G\&H) enzyme activities of stem cutting propagated Jatropha accessions at 180 DAT and 360 DAT. Vertical bars represent means $\pm S E(n=5)$; Different letters on the top of bars denote significant differences. The small letters and capital letters indicate significant differences in salt treatments within each accession and among accessions for the same treatment, respectively, at $\mathbf{p} \leq \mathbf{0 . 0 5}$ according to the post hoc test. 

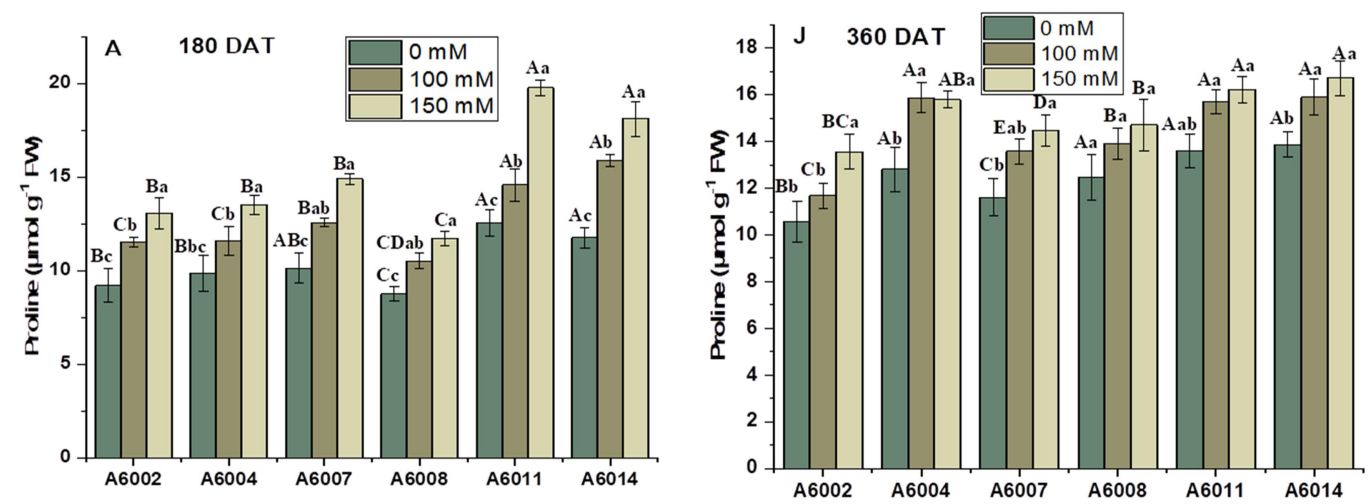

Figure 6. Effect of $\mathrm{NaCl}(0,100$, and $150 \mathrm{mM})$ treatments on free proline levels $(\mathrm{A} \& \mathrm{~B})$ of stem cutting propagated Jatropha accessions at 180 DAT and 360 DAT. Vertical bars represent means $\pm \operatorname{SE}(n=5)$; Different letters on the top of bars denote significant differences. The small letters and capital letters indicate significant differences in salt treatments within each accession and among accessions for the same treatment, respectively, at $\mathbf{p} \leq \mathbf{0 . 0 5}$ according to the post hoc test.

\section{DISCUSSION}

Roots have a high degree of developmental flexibility, are sensitive to soil pressures, and frequently adapt to their surroundings. Because the root system is in close touch with the growth medium, it provides essential nutrients to growing plants. Sound root systems can boost plant development and yields; hence, rooting behavior can provide helpful information about a plant salt tolerance capacity. $\mathrm{NaCl}$-induced salinity stress altered the plant growth and root system architecture [23-25]. Compared with the root morphology under the no- $\mathrm{NaCl}$ treatment, the root traits (i.e., root volume, root length, root diameter, root dry weight) of Jatropha accessions propagated by stem cuttings significantly altered with increasing concentrations of $\mathrm{NaCl}(100$ and $150 \mathrm{mM})$. However, considerable variations were observed among the accessions for root system traits under salt stress. Jatropha accessions A6002, A6004, A6008, and A6007 were raised by stem cuttings recorded with significant reduction of root dry weight when exposed to 100 and $150 \mathrm{mM} \mathrm{NaCl}$ for 360 days. But the A6011 and A6014 accessions showed no significant decrease of RDW at both salinity regimes and periods investigated (Fig. 1D).

Similarly, in A6002 A6004, A6011, and A6014 accessions grown from transplanted stem cuttings, the drop in root length, root diameter, and root volume were not significant (Fig.1A-C ) suggest that stem cuttings of A4, A11, and A14 accessions resulted in more incredible root system than A2 and A7 accessions. Our results are in coherence with the findings of $\mathrm{Li}$ et al. (2019), who observed that increasing $\mathrm{NaCl}$ salinity $(28,74$, and $120 \mathrm{mM})$ reduced the root length, dry weight, root diameter, and 
root volume in tomato (Solanum lycopersicum) plants. Rooting of Tamarix chinensis Stem cuttings irrigated with saline solutions was reduced as the number of roots. Root length, root dry weight (Li et al., 2010). Recently, a similar root morphology response to $\mathrm{NaCl}$ salt stress was observed in Suaeda salsa and Beta vulgaris L and rice [26]. Various reasons for the reduced root growth under salt stress are possible. High salinity leads to the accumulation of sodium and chloride ions hinders root growth, particularly the creation and development of lateral roots, by reducing cell division and elongation and altering the progression of the cell cycle. The inhibition of the root growth leads to the slowing down of the water absorption and of mineral elements and consequently affects the growth of the whole plant [27]. From this study, it can be suggested that accessions with deeper rooting can sustain plant growth under salinity conditions and thus potentially contribute to the plant tolerance to salt stress.

In this study, $\mathrm{NaCl}$ salinity stress significantly affected the shoot growth traits viz., plant height, shoot diameter, dry weight, and leaf area in Jatropha accessions. Significant $(p<0.05)$ degree of variation was observed for these parameters among the accessions under salt stress. Stem cutting propagated accessions A6002, A6004, A6007 and A6008 were suffered from poor shoot growth at $100 \mathrm{mM}$ and $150 \mathrm{mM} \mathrm{NaCl}$ concentrations at tested periods (Fig.2A-D). However, at $100 \mathrm{mM} \mathrm{NaCl}$ above accessions did not found to be experienced a significant reduction of plant height till 360 DAT. Further, $\mathrm{NaCl}$ salinity accounted for considerable inhibition of leaf area enlargement in A6002, A6004, A6007, and A6008 accessions (Fig. 2E\&F). From these results, it can be suggested that A6011 and A6014 accessions performed well under salinity conditions than other accessions. It was reported that the inhibition of plant height, diameter, number of leaves, and rooting in accessions of Jatropha propagated in sodic soils.

Similarly, $120 \mathrm{mM} \mathrm{NaCl}$ application reduced the leaf dry weight, shoot length, number of leaves, number of branches, and total leaf area in Vanda','P244601 verities of peanut (Arachis hypogaea L.) [28]. Earlier it is discovered that 100 and $200 \mathrm{mM} \mathrm{NaCl}$ treatments for 240 DAT decreased the basal diameter, total height, number of lateral shoots, the total length of lateral shoots, total leaf area, fresh \& dry weight of roots and lateral shoots in four olive cultivars (Fadak 86, Arbequina, Koroneiki, and Royal de Cazorla) [29]. Only at $200 \mathrm{mM} \mathrm{NaCl}$ at 240 
DAT did the leaf, shoot, and root dry weight decrease significantly. Fadak 86 demonstrated a greater reduction of plant growth traits than Arbequina, Koroneiki, and Royal de Cazorla, indicating salt tolerance. Plant growth is hampered by salinity because of a salt-induced water deficit and nutritional imbalance. Salt ions compete with enzymes involved in the uptake and transport of important nutrients within plants. High salinity lowers soil osmotic potential, making it difficult for roots to take up water by osmosis. Due to the accumulation of $\mathrm{Na}^{+}$and $\mathrm{Cl}^{-}$ions, high salinity causes (ion) toxicity stress, resulting in delayed cell cycles and cytotoxic effects, as well as a detrimental impact on wall remodeling and cell expansion enzymes (Xyloglucan endotransglucosylase and expansin) [30]. RNA-Seq transcriptome analysis of Jatropha found that the XTH enzyme is involved in wall remodeling and cell expansion and that exposure to $150 \mathrm{mM} \mathrm{NaCl}$ reduced plant growth [31].

A significant negative association between salt content and photosynthesis has been shown in numerous investigations [32, 33]. Our results show marked reduction of photosynthesis rate $(\mathrm{Pn})$, stomatal conductance (Gs), and transpiration rate (E) was observed in stem cuttings established for
Jatropha accessions subjected to $\mathrm{NaCl}$ treatment for 360 days (Fig.3A-F). It has been stated that $\mathrm{Na}+$ and $\mathrm{Cl}^{-}$accumulation under salinity have been shown to have a direct effect on the photosynthetic apparatus by reducing the efficiency of ribulose-1 5bisphosphate carboxylase (Rubisco) and ribulose-1,5-bisphosphate (RuBP) in the Calvin cycle, as well as the activities of stromal fructose bisphosphatase enzymes [34]. Our results are consistent with previous findings in tomato, castor, groundnut, and Pongamia [35, 36]. Similar reductions in Pn, Gs, and $\mathrm{E}$ indicate that stomatal opening limitation was the primary cause of photosynthetic limitation caused by increased salinity. Plants with high Gs have better $\mathrm{CO}_{2}$ diffusion into the leaf, favoring faster photosynthetic rates and growth [37]. In the present study, $\mathrm{NaCl}$ lowered the permeability of $\mathrm{CO}_{2}$ flow in leaves and positively correlated with reduced $\mathrm{Pn}$ and the growth of Jatropha (Fig. 3A\&B). There was a significant variance in SPAD chlorophyll content across the accessions under salinity conditions. Salt (100 and $150 \mathrm{mM} \mathrm{NaCl}$ ) treatment at both periods was investigated significantly decreased the SPAD chlorophyll levels in A6002, A6004, A6008, and A6007 accessions (Fig.3G\&H). Under salinity conditions, chlorophyll content was 
relatively greater $(\mathrm{p}<0.05)$ in the $\mathrm{A} 4, \mathrm{~A} 11$, and $\mathrm{A} 14$ accessions. Toxicity of $\mathrm{Na}^{+}$and $\mathrm{Cl}^{-}$ under salinity induces chlorosis stress by decreasing the chlorophyll biosynthesis and chlorophyll deficiency that hampers photosynthesis [38, 39]. Examining individual accessions revealed that A6002, A6008, and A6007 are sensitive to salinity as they experienced a significant reduction of Pn, Gs, and E following the 360 DAT. While the A6004 accession is somewhat vulnerable to salt stress, the A6011 and A6014 accessions are salt-tolerant, with no significant loss in Pn, Gs, or E. (Fig.1 A-F). Our results suggest that $\mathrm{NaCl}$ stress decreases Gs and photosynthetic activity, which may inhibit whole-plant growth.

In plants, salt stress causes both ionic toxicity and osmotic stress to plants which leads to the production of excessive reactive oxygen species (ROS) such as singlet oxygen $\left({ }^{1} \mathrm{O}_{2}\right)$, superoxide radical $\left(\mathrm{O}_{2} \cdot{ }^{-}\right)$, hydrogen peroxide $\left(\mathrm{H}_{2} \mathrm{O}_{2}\right)$, and hydroxyl radical $(\mathrm{OH} \cdot)$ called oxidative burst [40, 41]. Excess ROS damages membrane lipids, proteins and, DNA and distorts genomic stability by inducing crosslinks, base modification, or deletion. Plants deploy a set of antioxidant machinery to maintain ROS homeostasis and prevent oxidative damage caused by ROS under stress conditions [42]. In plants, SOD is the first line of defense against ROS, and it catalyzes the dismutation of $\mathrm{O}_{2}{ }^{-{ }^{-}}$to $\mathrm{H}_{2} \mathrm{O}_{2}$ and oxygen [43]. Further, $\mathrm{H}_{2} \mathrm{O}_{2}$ is converted to water and oxygen by CAT, APX, and GR enzyme actions [44]. The data obtained in this experiment exhibited that the SOD, CAT, APX, and GR enzyme activities were increased in Jatropha accessions subjected to the $100 \mathrm{mM}$ and $150 \mathrm{mM} \mathrm{NaCl}$ treatment. However, their response has differed among the accessions significantly. These enzyme activities were more significantly pronounced in A6011 and A6014 accessions at $150 \mathrm{mM} \mathrm{NaCl}$ at 360 DAT (Fig.5A-H). It was noted that the degree of enhancement of all the tested enzyme activities was more in stem cutting Jatropha accessions, indicating that A6011 and A6014 accessions have better defense against salinity stress over other accessions. At the highest salt level, antioxidant enzymes counteracted the adverse effects of ROS since the activities of SOD, CAT, APX, and GR enzymes increased. Still, MDA did not accumulate significantly in leaves of A6011 and A6014 accessions results, a degree of oxidative damage at the cellular level was mitigated (Fig.5A-H). It was noticed that the lipid peroxidation was more in A6002, A6004, A6007, and A6008 accessions at 100 and 150 $\mathrm{mM} \mathrm{NaCl}$ treatments at both periods tested 
(Fig.4A\&D), reflecting that A6011 and A6014 accessions are salt tolerant. To overcome the lowered water potential induced by saline soils, internal osmotic adjustments can be made by synthesizing compatible solutes such as proline, sugars, and glycine betaine $[46,47]$. In this study, cellular proline content significantly increased in all the Jatropha accessions with increasing $\mathrm{NaCl}$ concentration and time (Fig. 6I\&J). The Jatropha accessions A6004, A6011 and A6014 showed pronounced proline levels at $150 \mathrm{mM} \mathrm{NaCl}$ concentration at both tested time periods of the experiment, which displayed more excellent resistance to more severe treatment. Our findings match those of Guo et al. (2019), who found that electrolyte leakage and MDA concentration were considerably higher in the X45 cotton cultivar (salt-sensitive) than in the L24 cultivar (salt resistant) [48]. Both cultivars also increased SOD, POD, CAT activity, and proline, soluble sugar, and glycine betaine levels, which removed ROS and protected cell membranes. Compared to sensitive cultivars under salt stress, the L24 cultivar provided improved protection by increasing antioxidant enzyme activity. Similarly, transcriptome analysis revealed that thioredoxin, glutaredoxin, ascorbate, glutathione, SOD, CAT and POD genes were up regulated in salt-sensitive (Jc171) and down regulated in salt-tolerant (Jc183) Jatropha accessions under $150 \mathrm{mM} \mathrm{NaCl}$ salinity stress.

In conclusion, stem cutting raised Jatropha accessions exposed to $100 \mathrm{mM}$ and $150 \mathrm{mM}$ $\mathrm{NaCl}$ concentration for 360 days negatively affected the root morphology, shoot growth, and photosynthesis, but their response varied among the accessions. The root system parameters shoot growth and leaf area were significantly decreased A6002, A6004, A6007, and A6008 accessions at $100 \mathrm{mM}$ and $150 \mathrm{mM} \mathrm{NaCl}$ treatments at 360 DAT. Jatropha accessions A6011 and A6014 maintained the carboxylation efficiency when exposed to $150 \mathrm{mM} \mathrm{NaCl}$ at $360 \mathrm{DAT}$ as there was no significant decline in Pn, Gs, or E levels. Elevated antioxidative defense enzymes activities like SOD, CAT, APX and, GR and proline levels indicated that oxidative damage was inhibited, and membrane integrity was preserved in A6004, A6011, and A6014 accessions at both the salinity treatments. As a result, we conclude that the A6011 and A6014 accessions are potential candidates for future genetic improvement research involving the search for elite genotypes that are salinity resistant. These Jatropha accessions can be utilized to grow Jatropha in saline soils. However, more 
research is needed to explain variations in propagation, methods, and accessions, as well as the causes of these variances.

\section{Acknowledgment}

The authors are thankful to the Department of Botany, Osmania University, Hyderabad, Telangana, India, for providing the research facilities and support.

\section{REFERENCE}

[1] Hnilickova, H, Kraus, K, Vachova, P, Hnilicka, F, Salinity stress affects photosynthesis, malondialdehyde formation, and proline content in Portulaca oleracea L. Plants, 10, 2021, 845-859.

[2] Hussain S, Muhammad Shaukat, Muhammad Ashraf, Chunquan Zhu, Qianyu Jin, Junhua Zhang, Salinity Stress in Arid and Semi-Arid Climates: Effects and Management in Field Crops, Clim Chang Agri, 2019, 87982-87991.

[3] Kumar P, Sharma PK, Soil Salinity and Food Security in India, Front. Sustain. Food Syst, 4, 2020, 53378153790.

[4] Sharma D, Singh A, Salinity Research in India-Achievements, Challenges and Future Prospects, Water Energy Int, 58, 2015, 35-45.
[5] Yang Y, Guo Y, Elucidating the Molecular Mechanisms Mediating Plant Salt-Stress Responses, New Phytol, 217, 2018, 523-539.

[6] Van Zelm E, Zhang Y, Testerink C, Salt tolerance mechanisms of plants, Ann Rev Plant Biol, 71, 2020, 403433.

[7] Almeida DM, Margarida, Oliveira M, Saibo NJM, Regulation of $\mathrm{Na}^{+}$and $\mathrm{K}^{+}$homeostasis in plants: towards improved salt stress tolerance in crop plants, Genet Mol Biol, 10, 2017, 0106.

[8] Cruz JL, Coelho EF, Coelho Filho MA, Santos AA (2018) Salinity reduces nutrients absorption and efficiency of their utilization in cassava plants. Ciência Rural, 48: 1120.

[9] Li Y, Niu W, Cao X, Effect of soil aeration on root morphology and photosynthetic characteristics of potted tomato plants (Solanum lycopersicum) at different $\mathrm{NaCl}$ salinity levels, BMC Plant Biol, 19, 2019, 331-342.

[10] Cruz JL, Coelho Filho MA, Coelho EF, Santos AA, Salinity reduces carbon assimilation and the harvest index of cassava plants (Manihot 
esculenta Crantz), Acta Sci Agron, 39, 2017, 545-555.

[11] Loudari A, Chahinez Benadis, Rachida Naciri, Aziz Soulaimani, Youssef Zeroual, Mohamed El Gharous, Hazem M. Kalaji \& Abdallah Oukarroum, Salt stress affects mineral nutrition in shoots and roots and chlorophyll a fluorescence of tomato plants grown in hydroponic culture, Journal of Plant Interactions, 15(1), 2020, 398-405.

[12] Fukuzawa Y, Tominaga J, Akashi K, Yabuta S, Ueno M, Kawamitsu $\mathrm{Y}$, Photosynthetic gas exchange characteristics in Jatropha curcas L., Plant Biotech, 29, 2012, 155-162.

[13] Lamba Y, Jain S, Kumar S, A Review on Jatropha curcas derived biodiesel for economic and sustainable development bhawna, Intern J Emerging Technol, 11, 2020, 1026-1033.

[14] Mazumdar P, Pooja Singh, Subramanian Babu, Ramamoorthy Siva R, Harikrishna JA, An update on biological advancement of Jatropha curcas L.: New insight and challenges, Renew Sus Ene Rev, 91, 2018, 903-917.
[15] Silitonga AS, Masjuki HH, Mahlia TMI, Ong HC, Atabani AE, Chong WT, A global comparative review of biodiesel production from Jatropha curcas using different homogeneous acid and alkaline catalysts: Study of physical and chemical properties, Renew Sustain Energy Rev, 24, 2013, 514-533.

[16] Ploschuk EL, Bado LA, Salinas M, Wassner DF, Windauer LB, Insausti $\mathrm{P}$, Photosynthesis and fluorescence responses of Jatropha curcas to chilling and freezing stress during early vegetative stages, Environ Exp Bot, 102, 2014, 18-26.

[17] Singh B, Singh K, Shukla G, Goel VL, Pathre UV, Rahi TS, and Tuli $\mathrm{R}$, The field performance of some accessions of Jatropha curcas 1. (biodiesel plant) on degraded sodic land in north India, Int $\mathrm{J}$ Green Energy, 10, 2013, 1026-1040,

[18] Lowry OH, Rosebrough NJ, Farr AL, Randall RJ, Protein measurement with the Folin phenol reagent, J Biol Chem, 193, 1951, 265-275.

[19] Beauchamp CO, Fridovich I, Superoxide dismutase: improved assays and an assay applicable to 
acrylamide gels, Ann. Biochem, 44, 1971, 276-287.

[20] Nakano Y, Asada K, Hydrogen peroxide is scavenged by ascorbate specific peroxidate in spinach chloroplasts, Plant Cell Physiol, 22, 1981, 867-880.

[21] Aebi H, Catalase. In: Bergmeyer, HU (ed.), Methods of Enzymatic Analysis. Verlag Chemie/Academic Press Inc., Weinheim/NewYork, 1974， 673680.

[22] Bates L, Waldren RP, Teare ID, Rapid determination of free proline for water-stress studies, Plant and Soil, 39, 1973, 205-207.

[23] Karlova R, Damian Boer, Scott Hayes, Christa Testerink, Root plasticity under abiotic stress. Plant Physiology, 03, 2021, 1-14.

[24] Davis L, Sumner M, Stasolla C, Renault S, Salinity-induced changes in the root development of a northern woody species, Cornus sericea, Botany, 92, 2014, 597-606.

[25] Dinneny JR, Developmental responses to water and salinity in root systems, Ann Rev Cell Dev Biol, 35, 2019, 239-257.
[26] Vázquez-Glaría A, EichlerLöbermann B, Loiret FG, Ortega E, Kavka M, Root-System Architectures of Two Cuban Rice Cultivars with Salt Stress at Early Development Stages, Plants 10, 2021, 1194.

[27] Wang S, Zhao Z, Ge S, Peng B, Zhang K, Hu M, Mai W and Tian C, Root Morphology and Rhizosphere Characteristics Are Related to Salt Tolerance of Suaeda salsa and Beta vulgaris L., Front. Plant Sci, 12, 2021, 677767.

[28] Meguekam TL, Moualeu DP, Taffouo VD, Stützel H, Changes in plant growth, leaf relative water content and physiological traits in response to salt stress in peanut (Arachis hypogaea L.) varieties, Notulae Botanicae Horti Agrobotanici Cluj-Napoca, 49(1), 2021, 12049- 12057.

[29] Regni L, Del Pino AM, Mousavi S, Palmerini CA, Baldoni L, Mariotti R, Mairech H, Gardi T, D'Amato R, Proietti P, Behavior of four olive cultivars during salt stress, Front. Plant Sci, 10, 2019, 867-874. 
[30] Tenhaken $\mathrm{R}$, Cell wall remodeling under abiotic stress, Front. Plant Sci, 5, 2015, 771 .

[31] Paz de Souzaa MC, Daniel da Silvaa M, Binneckb E, André de Lima Cabrala, Iseppona ANM, Pompellic MF, Endresd L, Akio Kido E, RNA-Seq transcriptome analysis of Jatropha curcas L. accessions after salt stimulus and unigene-derived microsatellite mining, Industr crops prod, 147, 2021, 112168-112179.

[32] Rasouli F, Kiani-Pouya A, Tahir A, Shabala L, Chen Z, Shabala, S, A comparative analysis of stomatal traits and photosynthetic responses in closely related halophytic and glycophytic species under saline conditions, Environmental and Experimental Botany, 181, 2021, 104300-104312.

[33] Silas W, Rohit J, Singla-Pareek S, Pareek Ashwani, Photosynthesis and salinity: are they mutually exclusive, Photosynthetica, 56, 2018, 366-381.

[34] Yang Z, Li JL, Liu LN, Xie Q, Sui N, Photosynthetic Regulation Under Salt Stress and Salt-Tolerance Mechanism of Sweet Sorghum, Front Plant Sci, 10, 2020, 17221732.
[35] Zheng J, Suhono GBF, Li Y, Jiang MY, Chen Y, Siddique KHM, SaltTolerance in Castor Bean (Ricinus communis L.) Is Associated with Thicker Roots and Better Tissue K $+/ \mathrm{Na}+$ Distribution, Agriculture, 11, 2021, 821-830.

[36] Marriboina S, Sengupta D, Kumar S, Attipalli R. Reddy, Physiological and molecular insights into the high salinity tolerance of Pongamia pinnata (L.) pierre, a potential biofuel tree species, Plant Science, 258, 2017, 102-111.

[37] Pan T, Liu M, Kreslavski VD, Zharmukhamedov SK, Nie C, Yu M, Shabala S, Non-stomatal limitation of photosynthesis by soil salinity, Critical Reviews in Environmental Science and Technology, 16, 2020, 1-35.

[38] Shah SH, Houborg R, McCabe MF, Response of Chlorophyll, Carotenoid and SPAD-502 Measurement to Salinity and Nutrient Stress in Wheat (Triticum aestivum L.), Agronomy, 7, 2017, 61-70.

[39] Turan S, Tripathy BC, Salt-stress induced modulation of chlorophyll biosynthesis during de-etiolation of 
rice seedlings. Physiologia

Plantarum, 153(3), 2014, 477-491.

[40] Huang H, Ullah F, Zhou D-X, Yi M and Zhao Y, Mechanisms of ROS Regulation of Plant Development and Stress Responses, Front. Plant Sci, 10, 2019, 800-810.

[41] Lamers J, van der Meer T, Testerink C, How plants sense and respond to stressful environments, Plant Physiol, 182, 2020, 1624-1635.

[42] Yang FY, Guo Y, Unraveling salt stress signaling in plants. Journal of Integrative Plant Biology, 60 (9), 2018, 796-804.

[43] Hasanuzzaman M, Bhuyan MHMB, Zulfiqar F, Raza A, Mohsin SM, Mahmud JA, Fujita M, Fotopoulos $\mathrm{V}$, Reactive Oxygen Species and Antioxidant Defense in Plants under Abiotic Stress: Revisiting the Crucial Role of a Universal Defense Regulator, Antioxidants (Basel), 29, 9(8), 2020, 681 .

[44] Guidi L, Tattini M, Antioxidant Defenses in Plants: A Dated Topic of Current Interest, Antioxidants, 10(6), 2021, 855-864.

[45] Sachdev S, Ansari SA, Ansari MI, Fujita M, Hasanuzzaman M, Abiotic Stress and Reactive Oxygen
Species: Generation, Signaling, and Defense Mechanisms, Antioxidants, 10, 2021, 277-286.

[46] Kibria MG, Hossain MA, Murata Y Hoque, MA, Antioxidant Defense Mechanisms of Salinity Tolerance in Rice Genotypes, Rice Sci, 24, 2017, 155-162.

[47] Jogawat, A. Osmolytes and their Role in Abiotic Stress Tolerance in Plants, Molecular Plant Abiotic Stress, 2, 2019, 91-104.

[48] Guo Huijuan Hu, Zhiqiang Zhang, Huimin Min, Wei Hou, Zhenan, Comparative Effects of Salt and Alkali Stress on Antioxidant System, Environment and ecology in Cotton (Gossypium Hirsutum L.) Leaves Open Chemistry, 17(1), 2019, 1352-1360. 